\title{
Research on Curriculum Design of Undergraduate Major of Visual Communication Design Based on the New Media Era
}

\author{
Pang Yingqing \\ Wuchang Shouyi University Institute of Art \& Design, 430060
}

Keywords: New Media Era, undergraduate major of Visual Communication Design, professional curriculum, exploration

\begin{abstract}
With the continuous progress of our social economy, the requirements for undergraduate professionals of Visual Communication Design are gradually increasing in the new media era. Therefore, colleges and universities must attach importance to industry needs and train professionals of Visual Communication Design through curriculum reform. Based on the new media era, this paper discusses and analyzes the curriculum setup of undergraduate major of Visual Communication Design.
\end{abstract}

\section{In the New Media Era, Demand for Talents of Visual Communication Design Industry}

With the continuous development of the economy and society, people's material conditions and living standards are constantly improving. At the same time, people's aesthetic level becomes higher and higher. Therefore, in the current recruitment market, the demand for talents in the field of Visual Communication Design is gradually increasing. It is not only graphic designers who are able to deal with some simple image processing and layout required, but also those visual designers, new media editors and mobile visual designers. For job seekers, requirements are not only just in the five aspects of copy writing, drawing, planning, communication and creativity, but also in different directions. ${ }^{[1]}$ For example, it is required to use visual design to strengthen the visual appeal of the brand. At this time, the research, data analysis and information design must be implemented at the early stage of the design. When perfecting the planning and design of mobile terminal related software, it is necessary for job seekers to understand the hardware and design requirements of mobile terminals. At present, there is still a certain gap between talents in colleges and universities with those needed by the industry.

\section{China's Undergraduate Talents of Visual Communication Design Major in Colleges and Universities Fail to Meet the Industry's Needs}

In the teaching of undergraduate colleges and universities in our country, although the major curriculum of Visual Communication Design is constantly changing with the progress of the times, there is a certain gap between talents cultivated with those needed by the industry. This professional curriculum is not only limited to the professional courses of graphic design, but also introduce courses related to the new media and self-media, such as digital interactive design and UI interface design, but there is still a lack of information design and data analysis. For example, in a domestic Academy of Fine Arts, graphic design is a separate department, which includes four major directions: Graphic Design, Brand Design, Multidimensional Design and Publication Designer. General speaking, general professional courses for these four majors are basically completed in the first semester of sophomore period and students begin to learn professional courses in the second semester. Courses of visual design which take virtual media as the object are among the study of professional courses and the teaching as well as study are completed in studios. For example, the major course of Brand Design major in studios is Audio-visual Interactive Media Advertising and so on, while the major course of Multidimensional Design in studios is the Multidimensional Communication and Multidimensional Planning and Strategy. However, in the curriculum setting, information design and data analysis are not reflected. The effective training of students' innovative 
ability and creative thinking is not reflected.

\section{Curriculum Setup of Foreign Visual Communication Design Major}

The Visual Communication Design major of Chicago Art Institute and College of Visual Arts of New York ranks among the leading art schools in the United States. At Chicago Art Institute, Visual Communication Design major is similar to the Design major at the College of Visual Arts of New York. There are three similar aspects in the setting of professional curriculum between these two colleges. First, the courses of language expression are set in the teaching course. Courses related to language expression of Chicago Institute of Art include Truth, Perception and Story-telling in Artists' books. Those related to language expression in College of Visual Arts of New York conclude Visual Storytelling and Autobiography. Second, courses on information display and information design are set in the teaching courses at both two colleges. Envisioning Information, Analysis and Display are about information display and information design at the Chicago Institute of Art, while Communication Graphic Design is the corresponding course at the College of Visual Arts in New York. Third, at the two colleges, professional curriculum is divided into two kinds of visual design which respectively take virtual media and physical media as the main objects. ${ }^{[2]}$

\section{Curriculum Reform Direction of Visual Communication Major in China}

In the era of rapid development of information technology, information acquisition and analysis have gradually played a more important role in people's work and life, thus resulting in information design. Frank Thiessen proposed in Digital Information Design Dictionary that "Information design is a clear and effective presentation of information". Although the word "information design" is produced in the modern era, in the early days of human society, such activities have already emerged. For example, before words and languages appeared, people began to transfer information through certain body language and sound. With the development of modern society and the progress of science and technology, the world gradually entered the era of network, information and big data. Under this background, the presentation of information design gradually moves from static state to dynamic state, from two-dimension to multi-dimension, from entity to supposition, from one way to interaction. In the above-mentioned Chicago Institute of Art and College of Visual Arts of New York, courses of information design are offered in the Visual Communication Design major. Academy of Fine Arts of Tsinghua University has also set up Art and Technology major in 2010 and established the Department of Information Art Design in 2005. At present, there are not enough professionals of information design, but related work exists in most enterprises, especially in the industry of automobile design, product design and game development, etc. In information design, visual expression of information is a quite important content which makes information design as a part of professional curriculum system of Visual Communication Design major, so as to strengthen students' ability to deal with and analyze information. ${ }^{[3]}$

The degree of ability is directly determined by the cultural accumulation. In the current domestic university education, there is a general emphasis on the cultivation of professional knowledge and skills but none on the cultivation of humanistic quality. Although students are able to adapt to the society quickly after graduation which is also an important reason why most colleges and universities pay more attention to the cultivation of humanistic quality and emphasize general education, due to the deficiency of humanistic accumulation, they lack creativity in their work. In teaching, the follow-up education of courses of philosophy, literature and social science is also essential. These can be added to the teaching system as elective courses to enrich the curriculum type and strengthen the education of students' humanistic quality.

The so-called large curriculum mainly includes professional core courses, as well as some with relatively more levels and contents, such as graphic design course and typesetting design course. In the teaching of Chicago Institute of Art in the United States, the plane design course and typesetting design course are divided into two stages to teach. In plane design, courses in the first stage is to outline the knowledge related to graphic design major. Courses in the second stage is to enhance 
students' ability to organize information and pictures in the process of practical operation, as well as increase their awareness of problems, so that their visual thinking and integrated thinking will be gradually improved. This part of teaching process mainly emphasizes the scheme feasibility and the flexibility of teaching methods. ${ }^{[4]}$ In design of typesetting, the first stage of courses is to teach the knowledge of technology and the historical development of typesetting. The second stage is mainly to combine typesetting knowledge in the first stage with information theory, font design and publishing language organization, so as to enable students' works to get better communication. The application of segmentation method can be more conducive to the curriculum's gradual progress and help students understand the difficult part of courses.

According to the development of today's society and the demand of market, the project can be used as the leading role in the comprehensive training courses. Through the introduction of different professional teachers and students, the task can be completed in the same project group. Before a comprehensive training course is carried out, instructors and students can work together to make plans for the project and divide the task to ensure to play students' advantages. In the course of comprehensive training course, instructors should assist students and answer their questions. This form of project group is more conducive to the cultivation of compound talents. For example, in the design project of a product, students of industrial design and students of graphic design can be placed in a group to play their own advantages, which will not only improve the efficiency of work greatly and the level of scheme design, but also can expand their learning areas and stimulate them to learn from each other, so as to improve the team collaboration ability. ${ }^{[5]}$

A professional curriculum system usually includes a variety of related courses, and there must be a certain relationship among them. The penetration and relevance of courses will be more conducive to their longitudinal link. At present, in the teaching of colleges and universities in China, teachers only pay attention to their own subject teaching, but lack enough communication with other teachers, which leads to the lack of links among related courses.

For example, in the professional courses of design major, there will be three kinds of major knowledge about plane composition, color composition and stereoscopic composition which are usually described as the basic knowledge. Some colleges and universities divide these major components into three courses, while some divide them into two, and some even make them directly to one. There exists a common problem in different colleges and universities. Although students do not feel very difficult during the course, they cannot be effectively applied what they have learned to the design. The main reason for this problem is that students do not find vertical links among courses. ${ }^{[6]}$ To solve this problem, we can integrate contents of comprehensive design into construction design course. For example, it is feasible to use the composition rules of gradual change, repetition, launching and so on to design symbols and fonts, use formal beauty rules in illustration design, and introduce concrete cases to plane composition course. In this way, students are able to understand the importance of plane composition course and the relationship with follow-up courses as well as accurately locate the curriculum and strengthen their study.

\section{Conclusion}

With the continuous progress of the society, the demand for professional talents of Visual Communication Design major in the New Media Era is changing. Therefore, colleges and universities should pay attention to the training of professional talents of Visual Communication Design. It is necessary to reform the setting of curriculum by combining the industry's needs, so as to foster qualified professionals of Visual Communication Design major.

\section{References}

[1] Zhou Xiaoxu, Ding Yuehua. Curriculum Setup of Undergraduate Visual Communication Design Major in the New Media Era [J]. Art Education Research, 2018 (06): 98-100.

[2] Ren Wei. Problems and Countermeasures of Courses of Visual Communication Major in 
“Internet Plus Era” [J]. Art Technology, 2017, 30 (03): 83.

[3] Li Yuliang. Research on the Training Mode of Undergraduate Talents Based on "Visual Communication Design +" [J]. Journal of Industrial and Commercial University of Chongqing (NATURAL SCIENCE EDITION), 2016, 33 (01): 108-111+115.

[4] Cao Shu. Research on the Innovation and Reform of Applied Undergraduate Course -Taking Visual Communication Design Major as an Example [J]. Modern Decoration (Theory), 2016 (06): 259.

[5] Dong Xia. Practical Teaching Reform Research on the New Undergraduate Visual Communication Design Major of Technology Applied Type [J]. Modern Decoration (Theory), 2016 (08): 271-272.

[6] Hao Shubao. Exploration of the Curriculum System and Applied Talents Training Mode of Visual Communication Design Major in Newly Established Colleges and Universities [J]. Art Education, 2015 (02): 217. 